\title{
Empathy's echo: post-apartheid fellow feeling
}

\author{
Ross Truscott
}

\begin{abstract}
The concept of empathy has been set to work, across a range of fields, to mark a break with the relational patterns of apartheid. Similarly, empathy has been identified, historically, as that which, within apartheid and colonial rule more generally, exceeded or escaped relations of domination. This paper approaches the discourse of empathy from a different angle, taking empathy as a concept embedded in colonial thinking. Given that so many claims to empathy have had recourse to psychoanalysis, the paper focuses on empathy in Freud's work, specifically Dora's case and Freud's analysis of Michelangelo's Moses, which are read alongside the images and installations of contemporary South African artist, Nandipha Mntambo, in particular her collection of images and installations in The Encounter. Three scenes are conjured wherein empathy confronts its impossibility, but rather than foreclose on empathy as a postapartheid condition, it is through the disclosure of the aporias of empathy that it might be brought into the realm of the ethical through a practice of reinscription and through the figure of Echo.
\end{abstract}

A man, to be greatly good, must imagine intensely and comprehensively; he must put himself in the place of another and of many others; the pains and pleasure of his species must become his own. ${ }^{1}$

We must catch the undoing moment of Echo as she attends, at a distance, every act of cultural narcissism. ${ }^{2}$

\section{Introduction}

Empathy is being posited as a threshold of post-apartheid transformation; it is said to mark, if not the arrival of a post-apartheid condition, then at least the assurance that things are on the right track. History textbooks, it is said, should cultivate empathy in school children. 3 Empathy is championed as a new relation between those apartheid inscribed as different and separated from each other. It is promoted as an affective relation that occurred in the blind spots and shadows of the colonial state, between anthropologists and their native

\footnotetext{
${ }^{1}$ Shelley, "A Defense of Poetry," 6.

2 Spivak, "Echo," 27.

${ }^{3}$ Morgan, "Typecast-Or Getting to Know You," 26.
} 
informants, say, or between ethnographic photographers and their subjects. 4 Now that the apartheid state has been dismantled, empathy can return from hiding, come out into the sun, and fellow feeling will reign. It is in the public domain that empathy advocacy is perhaps loudest and most sure of itself. A former Constitutional Court judge, for instance, has stated in a recent public lecture that the Constitution of the Republic of South Africa is in fact an elaborate call to empathy that asks us to put ourselves in the place of other South Africans. 5 An injunction, we might say, taken literally by Julian and Ena Hewitt, the middle-class white couple who moved into the township of Mamelodi with their two children to see what it was like to live without water and electricity, an "experiment in empathy" that drew mixed responses. ${ }^{6}$

The point here is not to foreclose on empathy as a post-apartheid condition.7 The aim, rather, is to offer a critique that might make the concept of empathy adequate to the historical moment in which South African psychosocial transformation has shuddered and stalled. In staging my concerns, I take the work of South African artist, Nandipha Mntambo, specifically her collection of installations and images in The Encounter, as a provocation that asks us to think again about empathy. ${ }^{8}$ Leaning on Souleymane Bachir Diagne's African Art as Philosophy, I take Mntambo's The Encounter as a philosophical accomplice rather than an analysand. ${ }^{9}$ In short, I want to think with Mntambo's The Encounter rather than about her artwork.

It has been suggested that Mntambo's work, like that of photographer Zanele Muholi, elicits empathy from the viewer, that it, too, is a call for empathy..$^{10}$ It is worth briefly following the contours of this claim. Regarding Muholi's work, Tamar Garb, for instance, argues that photographic history provides a resource, not only of critique but of play. Deadly serious about the visual clichés of an oppressive iconographic tradition, she, like the people she portrays, feels free to use them as she likes, exposing their ethnic essentialism while queering their modes of address. ${ }^{11}$

\footnotetext{
${ }^{4}$ John and Jean Comaroff, for example, refer to Isaac Schapera as "the ethnographer with an uncommonly empathetic connection to the Africa in which he was born." Elizabeth Edwards, too, suggests that colonial domination was "tempered at an individual level by genuine desire for sympathetic understanding of peoples in human terms." Comaroff and Comaroff, "Portraits by the Ethnographer as a Young Man," 12. Edwards, "Introduction," 6.

${ }^{5}$ Du Plessis, "Have Empathy, that's What You Can Do for Constitutional Democracy - Kate O’Regan,” online.

${ }^{6}$ Polgreen, "An Experiment in Empathy," 1, 4.

${ }^{7}$ Indeed, empathy may allow us to hold onto the distinction between what Kaja Silverman calls "idiopathic identification," which is an "incorporative model, constituting the self at the expense of the other," and "heteropathic identification," which has an "externalizing logic," for it "locates the self at the site of the other." Silverman, "Masochism and Male Subjectivity," 52.

${ }^{8}$ Mntambo, The Encounter.

${ }^{9}$ Diagne, African Art as Philosophy: Senghor, Bergson and the Idea of Negritude. In Senghor, there is an interesting figuring of empathy as well, which he incorporates in part from ethnologist, Leo Frobenius, and philosopher, Henri Bergson, rewriting Einfühlung and intuition as rhythm. This is however beyond the scope of this paper.

${ }^{10}$ The literature on Mntambo's and Muholi's work, often discussed together, is mountainous and uneven. For reasons of space, I do not cite all of it here; though, for an explicit invocation of empathy in relation to Mntambo, see Sanger, "Imagining Possibilities: Feminist Cultural Production, Non-violent Identities, and Embracing the Other in Post-colonial South Africa." Ruth Lipschitz has written an excellent essay on Mntambo's work and also suggests something like empathy; see Lipschitz, "Skin/Ned Politics: Species Discourse and the Limits of 'the human' in Nandipha Mntambo's Art." For a reading attentive to the reinscription of colonial visual codes as well as the wager of Muholi's affective politics, see Van der Vlies, "Queer Knowledge and the Politics of the Gaze in Contemporary South African Photography: Zanele Muholi and Others."

${ }^{11}$ Garb, "Figures and Fictions: South African Photography in the Perfect Tense," 17.
} 
Photography provided an efficient means through which the unfamiliar inhabitants of the colonized world could be organized into apparently coherent entities and groups for scrutiny, study and delectation by outsiders. In fact it often provided the ground of their intelligibility, and the generic took precedence over the particular. But sometimes the photographs captured distinctive and unique physiognomies and features, and it is possible that empathy was also in place, despite the display of difference and the play of power that exposure to the camera entailed. ${ }^{12}$

In so many readings of Muholi's images, empathy appears, as it does for Garb, as a possibility that exceeds the colonial visual codes that Muholi reworks. Like Muholi, Mntambo works within and against a tradition of imaging, but what Mntambo's queers is precisely the empathic gaze. This, at least, is this argument toward which I am heading.

A part of The Encounter consists of installations made of cowhides, molded on the female body, both the artist's body and her mother's (Figure 1). If empathy, as Clifford Geertz puts it in his lecture, "From the native's point of view," discussing the scandal of Malinowski's A Diary in the Strict Sense of the Term, is "a task at least as delicate, if a bit less magical, as putting oneself into someone else's skin," 13 then Mntambo "invites the viewer to take her place, to step into the outline of her body, the molded cowhide." 14 While these installations do provide a comment on empathy, it is in her image, "The rape of Europa" (Figure 2) that, I think, empathy's latent libidinal economy is best grasped, and it is to this image that I return below.

\footnotetext{
12 Ibid., 21.

${ }^{13}$ Geertz, "'From the Native's Point of View': On the Nature of Anthropological Understanding," 29.

${ }^{14}$ May, "The Horns of a Dilemma," online.
} 


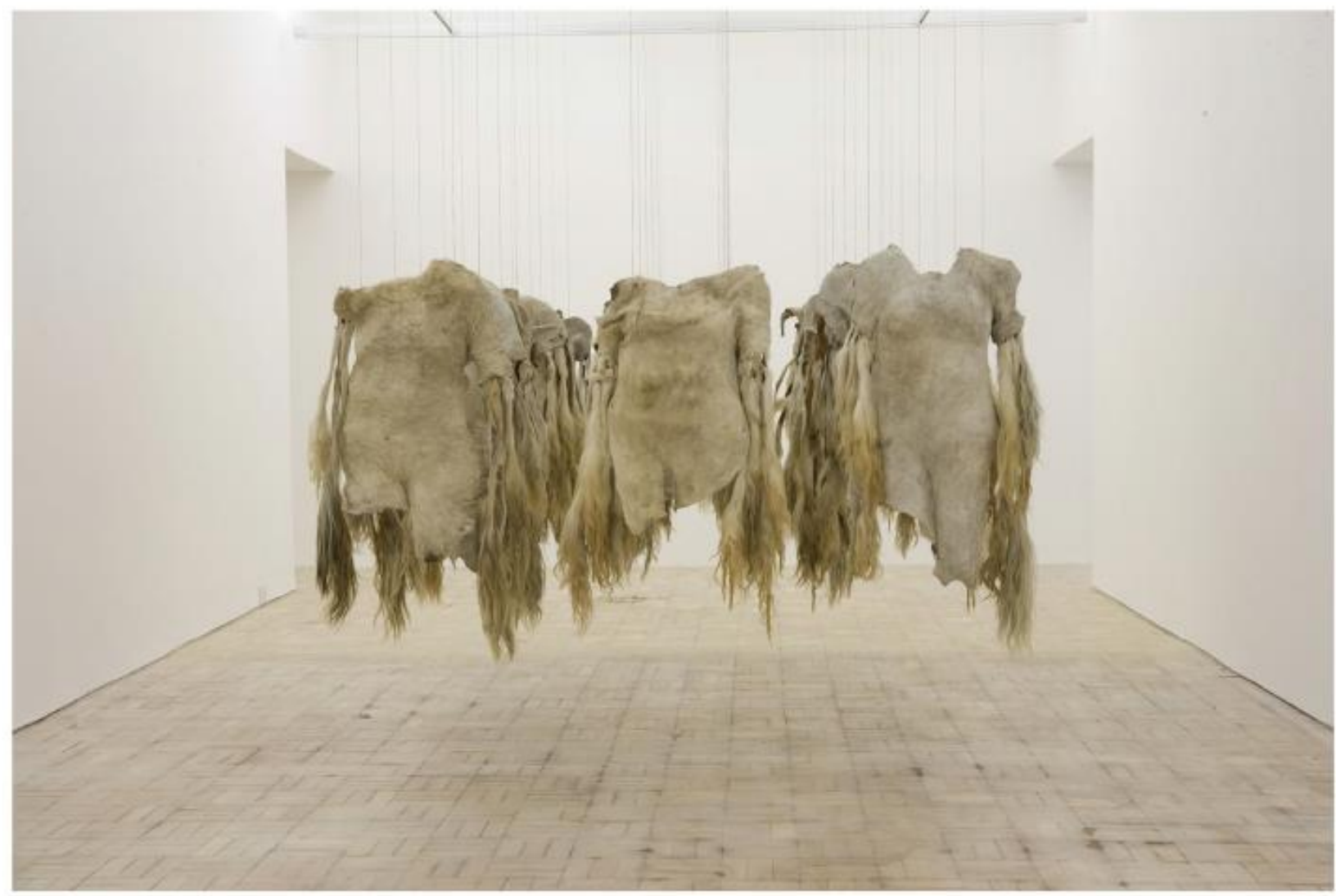

Figure 1. "Emabutfo" $\odot$ Nandipha Mntambo courtesy STEVENSON Cape Town and Johannesburg. 


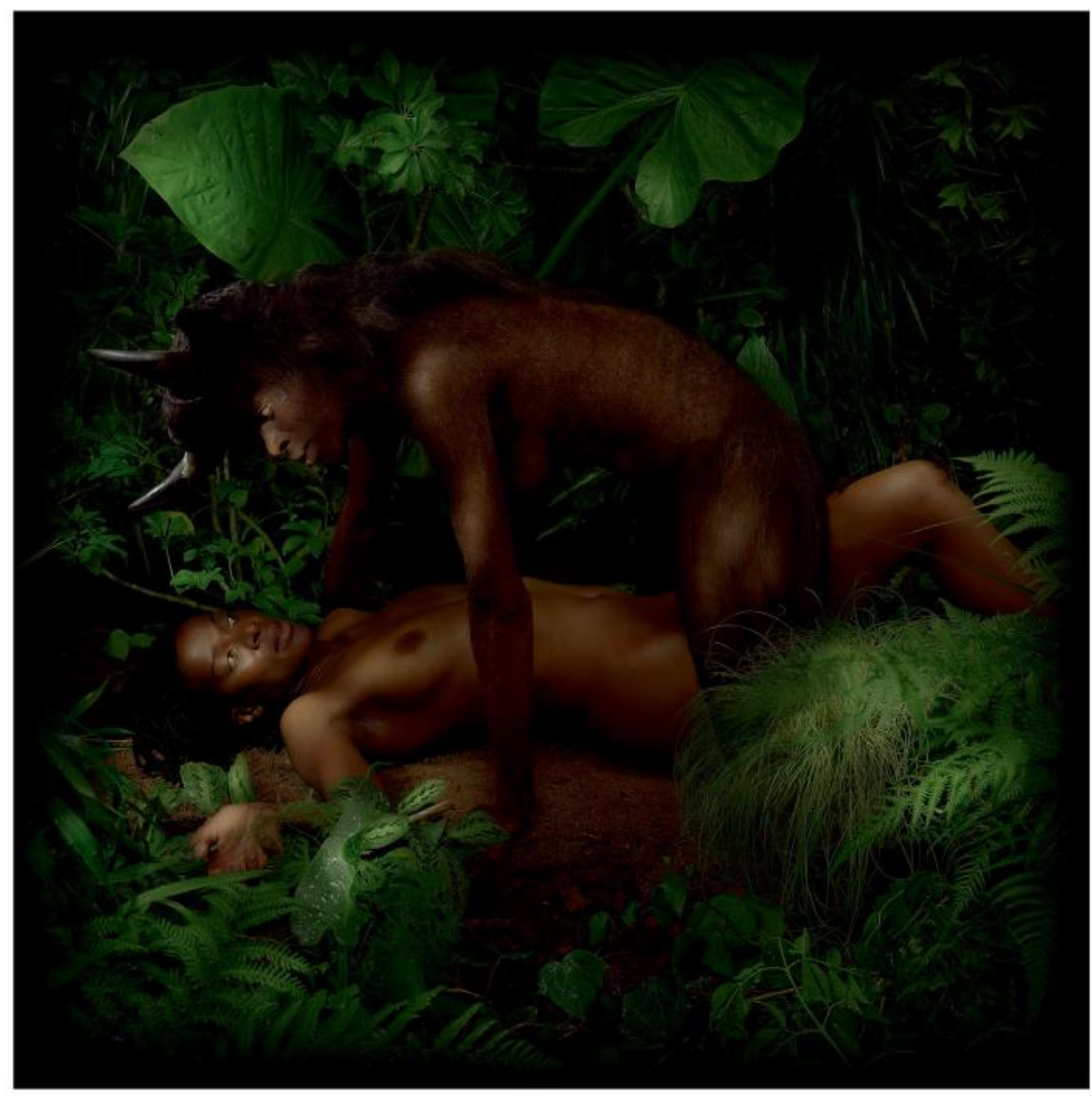

Figure 2. "The rape of Europa" ( $)$ Nandipha Mntambo courtesy STEVENSON Cape Town and Johannesburg.

Mntambo's reproductions of canonic images not only trouble the cult value of Western art, to use Walter Benjamin's terms, eroding the privileges that accrue with auratic perception, bringing about an equality of access, opening the way for the introduction of politics into art. ${ }^{15}$ What is at stake in Mntambo's work is also a somewhat different sense of access. What I focus on here is what she makes available to critical thought. As I see it, she offers a mode of inhabiting the discourse of apartheid so as to forge an exit from it through repetition or, rather, reprisal.

\footnotetext{
15 Benjamin, "The work of art in the age of its technological reproducibility," second version of the essay, first published 1989, composed 1935. See The Work of Art in the Age of its Technological Reproducibility and Other Writings on Media (2008).
} 
At a moment when student movements are coalescing around "black pain," it seems worthwhile pausing over what has become an assumed good, an ethical response affirmed without question. ${ }^{16}$ The claim to empathy as a post-apartheid condition, however, is not new.

Around the Truth and Reconciliation Commission of South Africa (TRC), it was argued, largely in the language of psychoanalysis, that empathy stands as a break with patterns of colonial and apartheid domination, the most well-known case being A Human Being Died that Night, Pumla Gobodo-Madikizela's account of her interviews with Eugene de Kock, commanding officer of apartheid's counterinsurgency police unit at the notorious Vlakplaas, with whom she came to identify and empathize, their encounter awakening his "human" capacity for empathy. ${ }^{17}$ It is this particular kind of argument that I want to pressure here.

In what follows, I offer a reading of empathy as it appears in Freud's writings, the logic being that if so many calls for empathy have drawn on psychoanalysis, a close reading of Freud will allow us to think through the undisclosed itineraries of subjectivity to which the concept of empathy commits post-apartheid transformation. ${ }^{18}$ I focus here on the following two texts: "Fragment of an Analysis of a Case of Hysteria," Dora's case, which opens onto the long and complex tangle between hysteria, art, and empathy, and "The Moses of Michelangelo." 19

Civilization and its Discontents is often taken as Freud's definitive rejection of the commandment to love thy neighbor as thyself. For many, Freud argues, their neighbor is not someone to love, but an object from which to extract what one needs, an object with which to satisfy aggression, to hurt, rape, even kill. "Homo homini lupus," man is a wolf to man, as Freud cites Plautus.20 This is not to say that empathy does not feature in Freud's writings. The impression in the Anglophone world that Freud is simply against empathy is, as George Pigman suggests, largely an effect of the Standard Edition translation of Freud; it was not Freud but James and Alix Strachey who were against the term. ${ }^{21}$ As Pigman argues, Einfühlung, the German term from which empathy is an early twentieth-century translation, is “an essential component of Freud's technique, a prerequisite for interpretation.”22

\footnotetext{
${ }^{16}$ As an exemplar of official institutional response to the tumult of the Fees Must Fall movement, the Vice Chancellor of the University of the Western Cape has stated: "I must say again as an institution we cannot begin to describe the deep empathy we feel for parents and students that have been traumatized by this and whose lives have been disrupted and put on hold" (https://www.facebook.com/UWCOnline-University-of-the-Western-Cape-194989287319013/?fref=ts). The critique of empathy I derive from Mntambo's work, however, is also a markedly different tack to that of "decolonization," on which much student politics is being waged, a dialectical negation of the normativity of whiteness.

${ }^{17}$ Gobodo-Madikizela, A Human Being Died that Night.

${ }^{18}$ In the interests of space, I have not cataloged all psychoanalytic interventions that proffer empathy in South Africa. For a good recent sample, however, see Smith, Lobban, and O'Loughlin, eds. Psychodynamic Psychotherapy in South Africa: Contexts, Theories, Applications. Almost all the chapters of this volume share the notion that apartheid arrested a capacity for empathy and that the work of clinicians and academics who think psychoanalytically but situate themselves outside institutional psychoanalysis might be to restore such a capacity. See also Coetzee and Kurtz, The Good Story: Exchanges on Truth, Fiction and Psychotherapy.

${ }^{19}$ Freud, "Fragment of an Analysis of a Case of Hysteria," 7; and Freud, "The Moses of Michelangelo," 210-38.

${ }^{20}$ Freud, "Civilization and its Discontents," 111.

${ }^{21}$ Pigman, "Freud and the History of Empathy."

${ }^{22}$ Ibid., 246. The first reference to empathy occurs in Edward Titchener's discussion of "kinaesthetic imagery." Tichener, Lectures on the Experimental Psychology of the Thought-Processes, 21-22.
} 
It is not, however, only a matter of translation, the Stracheys searching for English words with which to conceal a term they abhorred. For Freud, "the process which psychology calls 'empathy' [Einfühlung] ... plays the largest part in our understanding of what is inherently foreign to our ego in other people [das Ichfremde anderer Personen]." 23 Crucial as it is to psychoanalysis, Einfühlung is not, however, strictly speaking, a psychoanalytic concept; it predates the emergence of psychoanalysis, and was taken into psychoanalysis from elsewhere. Thus, just as psychoanalysis posits a subject that has, at its core, a foreign object, another, we find this doubled at the level of psychoanalytic discourse: "empathy" - for Freud, a concept transposed from psychology, his "quotation marks" telling of this transposition - is essential to psychoanalytic practice and, at the same time, is a concept foreign to the discourse of psychoanalysis. ${ }^{24}$

"Empathy" was incorporated, at least in part, from the philosophical psychology of Theador Lipps, who provided the first theoretical elaboration of the concept.25 There is something intriguing about Lipps' conception of Einfühlung, which may work against the notion of a preconstituted sovereign subject. For Lipps, there is an "I" before Einfühlung, before an "I" has projected itself into the scene of an artwork or, as he develops the concept in his later work, into the place of another subject. This "I," however, emerges as the retroactive effect of a separation from this immersion: the dissolution of the boundaries between subject and object conditions the emergence of an "I." Thus, rather than simply a feeling in an already constituted subject, Einfühlung entails a feeling of oneness, a passage into another, dissolving boundaries, the emergence out of which constitutes an "I," afterwards. It is an "I" who will have felt his way into another. In short, the subject, for Lipps, is dependent on the other for its very existence. ${ }^{26}$ As Juliet Koss notes, however, paying attention to the scenes wherein such constitutive undoings of the frontiers between self and other take place for Lipps, the subject capable of Einfühlung was "implicitly a man of property whose identity was destabilized within the confines of a relatively private realm, carefully circumscribed by the laws of decorum and propriety." 27 What is never destabilized, Koss argues, are his elite status and his gender, which remain firmly intact however much one loses oneself in contemplation. Put bluntly, losing oneself and reemerging as an "I" requires access to certain things - a gallery or, ideally, a private parlor, perhaps a good whiskey and time to spare - that not everyone has.

\footnotetext{
${ }^{23}$ Freud, "Group Psychology and the Analysis of the Ego," 108.

${ }^{24}$ Jacques Lacan comments in his reading of Dora's case that what is constitutive of "psychoanalytic experience is that it proceeds entirely in a relationship of subject to subject." Considered alongside Freud's assertion that empathy is "the mechanism by means of which we are enabled to take up any attitude at all towards another mental life," one could say that "psychoanalytic experience" comes to hinge on empathy, even though, and perhaps precisely because, it is an impossible relation. Lacan, "Intervention on Transference," 93; and Freud, "Group Psychology," 110, n. 2. I read empathy here along a somewhat different line, but for a Lacanian treatment of empathy, see Žižek, Violence: Six Sideways Reflections, 4. Žižek renders empathy "a lure which prevents us from thinking." For a more considered Lacanian critique, see Neill, "Beyond Identification: The (Im)possibility of Loving thy Neighbor."

${ }^{25}$ With some certainty, we can say that it was while writing up Dora's case that Freud was reading Lipps. Freud, The Complete Letters from Sigmund Freud to Wilhelm Fliess: 1887-1904, 324, 329.

${ }^{26}$ See, for example, Lipps, "Empathy, Inner Imitation, and Sense Feelings," 371-78. On Lipps and empathy see Sawicki, "Empathy Before and After Husserl," 123-7.

${ }^{27}$ Koss, "On the Limits of Empathy," 144.
} 
In the next section, I turn to Freud's case study of Dora. In the section following this, I move to his reading of Michelangelo's statue of Moses. In each of these texts, empathy is at work. In the third section, I focus more closely on The Encounter. My aim in juxtaposing Mntambo and Freud is to conjure three scenes wherein empathy confronts its own undoing: its enjoyment, its violence, and its narcissism, each of which is commonly taken to be antithetical to the cultivated feeling and refined imagination of empathy.

\section{Dora's predator}

Dora presented with various symptoms, among them coughing, aphasia, dyspnoea, stomach pains, and a catarrh. She was brought to Freud by her father, Phillip Bauer, after he and Dora's mother discovered a suicide letter. She had accused her father of having an affair with Frau K., a family friend. Two years before, she had also accused Herr K. of making sexual advances toward her, indeed of pursuing her since she was 14. Though worried about Dora, her father took these accusations as the fancies of a young girl and asked Freud to bring her to her senses. For her part, Dora was furious; she suspected that she had been handed over to Herr K. as the price her father was paying for his ongoing affair. And now she had been handed over, once more, to Freud.

While taking Dora's accusations seriously, Freud interprets them. On the one hand, Dora behaved "like a jealous wife," protesting against a husband's infidelity, "clearly putting herself in her mother's place." The woman her father loved, however, was not her mother and she must also, Freud hypothesizes, "have been putting herself in Frau K's place." Dora was, thus, as Freud states, "identifying herself both with the woman her father had once loved and with the woman he loved now." 28 Extending these lines of Dora's identifications, Freud suggests that her symptoms concealed a secret love for Herr K., behind which was an oedipal wish. Thus, she was not simply afraid of Herr K.: she was afraid of her desire for him, her symptoms providing a means of refusing his advances, of getting him off her path, as it were, but also a means of disguising her desire. Freud's formulation is then given a further twist, which he elaborates for the most part in his footnotes. Dora was not only jealous of Frau K. (and her mother), in love with Herr K. (and her father); she was also, Freud suggests, in love with Frau K. Indeed, Freud writes of "Dora's deep-rooted homosexual love for Frau K.," a love that was at the heart of her hysteria and which he failed to discern in time. ${ }^{29}$ Freud is frequently charged with "lack of empathy with Dora,"30 "a lack of empathy with a suffering adolescent girl being victimized by egoistic adults." ${ }^{11}$ Registering the possibility of such a charge, Freud states in his preface that "the exacting demands which hysteria makes upon a physician and investigator can be met only by the most sympathetic spirit of inquiry [liebevollste Vertiefung] and not by an attitude of superiority and contempt."32 Taking Freud at his word, it has also been persuasively argued that he did in fact put himself into Dora's psychic world, that he did empathize with her, and that it is this, rather than his lack of empathy, that is so disquieting about the case. Claire Kahane suggests that, "as brilliant as

\footnotetext{
${ }^{28}$ Freud, "Fragment," 56.

${ }^{29}$ Ibid., 105, n. 2.

${ }^{30}$ Decker, Freud, Dora and Vienna 1900, 107.

${ }^{31}$ Gay, "Editor's Introduction: Fragment of an Analysis of a Case of Hysteria ('Dora')," 173.

${ }^{32}$ Freud, "Fragment," 15-6.
} 
Freud was in constructing a narrative of Dora's desire, he essentially represented his own."33 Steven Marcus, too, asserts, "The case history belongs progressively less to her than it does to him."34 Suzanne Gearhart writes of Freud's "identification with Dora," a part of his countertransference. 35 And Neil Hertz inquires into Freud's "unrecognized - or refused identification" with Dora, indeed, the ways in which "he 'was' Dora." 36

Freud's letters to Fliess certainly suggest that he had something like the pitfalls of empathy in mind - "that the 'reader of thoughts' perceives nothing in the 'other', but merely projects his own thoughts" - while writing up the case. 37 We might say that Freud does empathize with Dora, but that, in doing so, he situates himself, as Lacan argues, in the position of Herr K., he assumes or, rather, is cast, through the transference that ensues, into the role of Dora's sexual predator. $3^{8}$ The transference - as the impression an unremembered experience will have left in the interaction between doctor and patient, organizing their relationship - puts Freud in Dora's tracks, as it were.

In Freud's case study of Dora, there are two figures of empathy. The first is Freud. The second is Dora herself. Dora's symptoms allow her to put herself into the place of others. Dora's cough, a copy of Frau K.'s cough, allowed her to be like the lover of her father, assuming also the place of Herr K's wife. Her cough, which caused her to lose her voice at times, was, however, overdetermined, carrying several wishes; it was also, Freud states, "an imitation of her father," which enabled Dora to simultaneously occupy his place and express "sympathy [Mitleid] and concern for him," for his ill health, on account of which he would leave home to carry out his affair, an affair she lived, if only through her affliction, through her suffering. ${ }^{39}$ Her suicidal ideation, too, the very reason she was brought to Freud, declared her identification with her father, as on being discovered with Frau K., he had conjured a story of wanting to take his life, from which Frau K. had saved him. It is a love letter symptomatically addressed to Frau K., but like her cough, Dora's letter was overdetermined; it was also, Freud argues, a double of a letter written by a "maidservant" with whom Herr K. had conducted a brief affair. Indeed, it is in the role of the "maidservant" that the transference is acted out, Dora finally breaking with the treatment with Freud by giving him a "fortnight's warning, just like a governess," and assuming the fate of the "maidservant" whom Herr K. had taken and then cast aside. 40

\footnotetext{
${ }^{33}$ Kahane, "Introduction to Part Two," 20.

${ }^{34}$ Marcus, "Freud and Dora: Story, History, Case History," 85.

${ }^{35}$ Gearhart, "The Scene of Psychoanalysis: The Unanswered Question of Dora," 122.

${ }^{36}$ Hertz, "Dora's Secrets, Freud's Techniques," 67. Hertz's argument is especially compelling. For him, Freud sees reflected in the mirror of his analysand the conditions of possibility for psychoanalytic knowledge, "acquired," as Hertz puts it, "in a structure of Nachträglichkeit, analogous to the hysteric's acquisition of her often paralyzing secrets" (Hertz, "Dora's Secrets," 76).

${ }^{37}$ Freud, Letters from Sigmund Freud to Wilhelm Fliess, 450.

${ }^{38}$ Lacan, "Intervention on Transference."

${ }^{39}$ Freud, "Fragment," 82.

${ }^{40}$ Freud, "Fragment," 107. Indeed, Dora, the pseudonym Freud gave Ida Bauer, is the name of his sister's governess while he was a child, as Jacqueline Rose notes. Jacqueline Rose, "Dora: Fragment of an Analysis," 128-48. Read through a postcolonial frame, the figure of the domestic worker gives the case a set of racial associations that are not there or only latent in Freud's written text. This kind of reading is offered by artist, Penny Siopis who brings Dora and Saartjie Baartman into the same frame in her painting, "Dora and Other Women," positing something shared between these two women. At stake for Siopis is the way that both Dora and Baartman were made the object of a male gaze, though not in the same way. For a discussion of this, see Annie Coombes, "Gender, Race, 'Ethnicity' in Post-apartheid Art Practices: Annie Coombes and Penny Siopis in Conversation," 109-29.
} 
Rather than a mere object to be cured or understood, Freud confronts in Dora a figure who has taken to its breaking point the injunction - of which Percy Bysshe Shelley's "A Defense of Poetry" is merely the nineteenth century emblem - to "imagine intensely," to make "the pains and pleasure" of "many others" one's own. ${ }^{41}$

Whereas the first figure is one of predatory empathy, the second is in flight. Within more orthodox psychoanalytic theory, this pursuit would be taken as the acting out, between the analyst and analysand, of her traumatic experience, a repetition of her experience of pursuit in the transference, the transference being both the obstacle to, and the condition of possibility for, her cure. In this reading, it is a transference that merely happens to entail a pursuit. In its rhythms are the traces of her trauma, the key to her haunting memories, which can then be recalled, worked, through: Dora's experience of being prey to Herr K., compounded by her parent's complicity. But is this pursuit not, perhaps, an effect of empathy, empathy as an act that is of necessity predatory, an acting out not of her repressed memories but of the roles that empathy offers up? Reconciling these two hypotheses, we might say that it is both: the predation she experienced, which was repressed but echoed through her symptoms, organizing the transference, already entailed empathy. That is, if Freud is cast into the role of Herr K., Herr K. was not without empathy. At least, my reading of Mntambo's "The rape of Europa," when placed alongside Dora's case, leads toward this formulation.

In Ovid's Metamorphoses, which is usually taken as the literary source of the visual depictions of the rape of Europa, Europa is the Phoenician Princess Jupiter falls in love with. He changes himself into a white bull and descends to earth. On the seashore where Europa and her friends play, Jupiter seduces her, offers himself gently, coaxing her playfully. After placing flowers around his horns, Europa mounts his back, at which point Jupiter suddenly bolts, heads into the sea and swims with her on his back to Crete. While the Metamorphoses and the many paintings and sketches that depict Europa's rape only gesture toward the rape to come, Mntambo actually depicts the scene of rape, interpreting Europa's rape through Pablo Picasso's etching, "Minotaur caressing the face of a sleeping girl with his face." Indeed, Mntambo's image is, in terms of its composition, a quotation of Picasso.

If Mntambo's images offer a comment on post-apartheid empathy, it is perhaps because empathy is already written into the Ovidian narrative she interprets, at least into its secondary literature. It has been suggested that the frequency with which Ovid wrote about rape - the Metamorphoses contains more than 50 tales of rape ${ }^{42}$ and the intense fear in the women raped - is evidence of a kind of empathy on Ovid's part.43 Leo Curran argues that "flight was for Ovid the consummate means for the expression of the terror of the rape victim, the predatory appetite of the rapist, and the dehumanizing reduction of a woman to the level of a hunted animal." 4444 From this, Curran concludes that the hunt is "an excellent

\footnotetext{
${ }^{41}$ Shelley, "Defense," 6.

${ }^{42}$ Richlin, "Reading Ovid's Rapes."

${ }^{43}$ Richlin, "Reading Ovid's Rapes"; and Curran, "Rape and Rape Victims in the Metamorphoses."

${ }^{44}$ Curran, "Rape and Rape Victims," 280.
} 
poetic method for putting the reader into the position of the victim, since we have all experienced similar dread in our nightmares and there is a distinctly nightmarish quality in the flight scenes of the Metamorphoses."45 In short, Ovid asks his reader to empathize. Care should be taken wherever rape comes to stand in metaphorically for something else. 46 This, however, is precisely what is at stake in empathy as an ethical act whose form is by definition analogical. 47

It is the associative drift between empathy and sexual predation that Mntambo conjures through "The rape of Europa." Though it is Picasso's "Minotaur" that is the compositional reference point, through the titling of the image, it is the island of Crete, where Jupiter took Europa, that is conjured, some interior part of Crete, an enclosure in the trees, an enclosure that finds a miniaturized double in the enclosures of the installations made of cow hides, molded on the artist's body: a hollow in the trees, on the one hand, and the cavities of the hides, on the other. If the viewer is invited to imaginatively inhabit the molded hides, the skin of another, the image asks the viewer to identify with the Minotaur straddling Europa, put oneself into the enclosure, into the place of this figure in the act of rape. The viewer's gaze is made complicit through empathy from the start, one's eyes are drawn to the Minotaur's eyes, where the light strikes her directly, as if from your eyes; the passage of the light moves from the place of your gaze to the Minotaur's eyes, and from there to Europa, rebounding back to her hand, where - as if to give your gaze back to you, the viewer, return your empathic look - the circuit ends and begins again. "The rape of Europa," alongside Mntambo's cow hide installations, doesn't merely invite empathy; it solicits it and then holds up a mirror to it: see yourself in this scene, it says, imaginatively project yourself into the scene, and this will have been an image of your predatory look, erotic and violent. The circuit of light, repeated for as long as one stares at the image, becomes the thrusting of an empathic gaze.

Certainly one can no longer read Dora's case the same way after Mntambo's "The rape of Europa." One cannot but see Freud putting himself into Dora's psychic world, making "multiple analytic thrusts into her unconscious." 48 If Freud is thrown off by Dora, if his empathy is troubled, it is because he encounters in her an almost absolute, unstable empathy, confronting Freud with the difficulty of inhabiting the place of another who intensely enjoys putting herself in the place of others. Just as Mntambo places the empathic gaze within her frame and makes it glare back, in the hysteric, the second figure of empathy, the first figure, the "physician and investigator," encounters a disturbing reflection of his own enjoyment.

\footnotetext{
${ }^{45}$ Ibid, 280

${ }^{46}$ Richlin is certainly more cautious here - indeed her piece can be taken as a critique of this move - than Curran, whose claim is more than a little dubious.

${ }^{47}$ Given how Picasso is for "The rape of Europa" a reference point, it is worth noting that Martin Ries states of the Minotaur etching Mntambo echoes: "This is not the terrible monster from Crete but a sympathetic and pampered pet." Ries, "Picasso and the Myth of the Minotaur," 143.

${ }^{48}$ Rieff, "Introduction," xvii. Rieff's reading does discern something like empathy at work in Freud's approach, which turns on him seeing in her anger a conflict that he has already worked through in his self-analysis.
} 


\section{A fingerprint of fury}

As alluded to above with regard to Lipps, Einfühlung was a concept formed initially in the field of esthetics and only later posited as an intersubjective condition. 49 It is thus worth turning to a text wherein Freud is explicitly concerned with a work of art, "The Moses of Michelangelo," which will lead us further into the predatory elements of empathy.

Michelangelo's Moses, Freud tells his reader, had been interpreted as a "calm before the storm." As this interpretation goes, "[i]n the next instant Moses will spring to his feet - his left foot is already raised from the ground - dash the Tables to the earth, and let loose his rage upon his faithless people." 50 Projecting himself into the movement of the statue, specifically the movement of Moses' index finger caught in his beard, Freud produces a different hypothesis:

In imagination we complete the scene of which this movement, established by the evidence of the beard, is a part; and we are brought back quite naturally to the hypothesis according to which the resting Moses is startled by the clamour of the people and the spectacle of the Golden Calf. He was sitting there calmly, we will suppose, his head with its flowing beard facing forward, and his hand in all probability not near it at all. Suddenly the clamour strikes his ear; he turns his head and eyes in the direction from which the disturbance comes, sees the scene and takes it in. Now wrath and indignation lay hold of him; and he would leap up and punish the wrongdoers, annihilate them. His rage, distant as yet from its object, is meanwhile directed in a gesture against his own body. ${ }^{1}$

Freud sees in this "despotic finger" not the leader's rage to come, but "the remains of a movement that has already taken place," a sculpture of "frozen wrath," a hypothesis to which Freud is brought by imaginatively recreating the history of a gesture, putting himself into the scene of Michelangelo's Moses along three lines. $5^{2}$ First, he identifies with Michelangelo, an identification recruited by the artist, who, as Freud as suggests, "aims... to awaken in us the same emotional attitude, the same mental constellation as that which in him produced the impetus to create." Second, it is with "the angry scorn of the hero's glance" that he identifies. 53 An editorial footnote draws attention to Ernest Jones' speculation that Freud's interpretation of the sculpture as a departure from scripture - the scriptural Moses destroyed the Tables of the Law, Michelangelo's Moses, in Freud's analysis, preserves them, relinquishes the grasp of his beard, which was the displacement of fury at his rebellious followers - may have been influenced by his own fury at Jung and Adler.54 That is to say, Freud was moved by Moses, he identified with him as leader with a group in revolt, "struggling successfully against an inward passion for the sake of a cause to which he has devoted himself." 55 And third, telling of

\footnotetext{
${ }^{49}$ For a good summary of its early history, see Mallgrave and Ikonomou, Empathy, Form and Space: Problems in German Aesthetics 1873-1893.

${ }^{50}$ Freud, "The Moses," 216.

${ }^{51}$ Ibid., 224.

52 Ibid., 223, 229.

${ }^{53}$ Ibid., 212-3.

${ }^{54}$ Ibid., 230, n. 1. Jung and Adler were initially a part of Freud's inner psychoanalytic circle and later rebelled against the "master," particularly concerning sexuality as the source of neurosis.

${ }^{55}$ Ibid., 233.
} 
his many trips to see the statue of Moses, Freud states, "[s]ometimes I have crept cautiously out of the half-gloom of the interior as though I myself belonged to the mob upon whom his eye is turned." 56 That is, Freud locates himself in the scene as the object of this leader's fury, a part of a rebellious group.

In his interpretation, Freud draws on a technique of connoisseurship proposed by Giovanni Morelli, an Italian physician and art critic. Morelli's method, concerned with distinguishing copies from originals, considers, as Freud puts it, "the significance of minor details" as a kind of fingerprint of the artist left in "unconsidered trifles which the copyist neglects to imitate." Morelli's approach is a "method of inquiry," as Freud states, "closely related to the technique of psychoanalysis." Indeed, Freud notes the similarity between this method, his own, and detective work.57 Following this "minor detail," Carlo Ginzberg argues that what unites Morelli, Freud, and Sherlock Holmes is a common relation to medicine, more specifically, "the model of medical semiotics, or symptomatology." 58 Ginzberg suggests that lurking behind these three forms of "conjectural knowledge" is a common originary figure, "the hunter crouched in the mud, examining a quarry's tracks." 59 The hunter, as Ginzberg states, is "the hypothetical origin of the conjectural model."6o

Morelli wrote under a Russian pseudonym, Ivan Lermolieff, and Freud first published "The Moses of Michelangelo" anonymously. If this common concealment of identity recalls two hunters silently tracking their prey, there is nothing necessarily sinister about this for Ginzberg. Indeed, hunting, Ginzberg speculates, may have given rise to writing, the hunter, perhaps, "the first 'to tell a story' because only hunters knew how to read a coherent sequence of events from the silent (though not imperceptible) signs left by their prey." ${ }^{11}$ Ginzberg does, however, note that this mode of knowledge would come into play in colonial governmentality in the nineteenth century through an appropriation of the "conjectural knowledge" of colonized people, used against them: "The problem of identifying previous offenders, which developed in these years, was the bridgehead of a more or less conscious

project of keeping a complete and general check on the whole of society."62 Thus, the distance between the footprint of the prey in the mud, the fingerprint at the scene of the crime, and the photographic print in the identity document begins to narrow; all are traces that come to index knowledge of a subject who can be tracked, its history known, its predilections anticipated, controlled.

Buried in "The Moses of Michelangelo," I want to suggest, is a dialectic of rebellion (the disobedience of the people), retribution (the wrath of their leader), and the sublimation of aggression (the leader's restraint, which allows the Law to be preserved). Associatively read,

\footnotetext{
56 Ibid., 213.

${ }^{57}$ Ibid., 222.

${ }^{58}$ Ginzberg, Clues, Myths, and the Historical Method, 12.

${ }^{59}$ Ibid., 14.

${ }^{60}$ Ibid., 22.

${ }^{61}$ Ibid., 13.

${ }^{62}$ Ibid., 25.
} 
it is the rebellion of Freud's followers who would be crushed for their disobedience, were it not for the restraint of their magnanimous leader who brings himself under control. Latent, also, is of course Freud's own rebellion against the scientific community. There is, however, another and, for my purposes, more important associative track to this trace that Freud reads - literally, a fingerprint of fury, a "violent gust of passion visible in the signs left behind it in the ensuing calm"63 - and to this group in revolt, people formerly enslaved: the revolt of colonized people and the question of vengeance and retribution that arises there. Given that "primitive peoples" and children are notoriously rendered by Freud as mutually narcissistic, commonly afflicted by megalomania, perversion, and a predilection to oedipal defiance, the quelling of insurrections against the colonial state is latent in an essay Freud writes during the same period as his essay on Michelangelo's Moses, published in the same volume of the Standard Edition. "Only someone who can feel his way into the minds of children," Freud states, "can be capable of educating them; and we grown-up people cannot understand children because we no longer understand our own childhood." 64 One cannot but ask who else this statement might refer to, if not those "savages or half-savages" who, Freud writes in the opening page of "Totem and taboo," represent a "well-preserved picture of an early stage of our own development." 65 That is, "we no longer understand" the children of man. ${ }^{66}$

Freud, like the colonial state, is concerned with revolt - with the followers of Moses rebelling against their leader, with rebellious or, at least, badly behaved children and, associatively, with insurrectionary "savages or half-savages" - and the question of how to respond to it. There is, of course, a crucial difference between Freud and the discourse of the colonial state, as Freud insists that "forcibly suppressing such impulses" is futile, that its results are no better than "giving free play to children's naughtiness." 67 His response, rather, as his analysis of Michelangelo's Moses suggests, is education or, rather, leading by example: Moses quells his own fury, in the sculpture, "downwards from above," the face of Moses already brought under control, his leg not yet subdued, still cutting a path toward the people he would crush, as he crushed his beard, a displacement of fury that, turning on itself, is dissipated. ${ }^{68}$ This has a direct bearing on a history of psychoanalysis in South Africa, which is thought to reemerge with, and in the wake of, the TRC. 69 The most immediate precursor to the TRC, Adam Sitze, argues in The Impossible Machine, was the colonial commission of inquiry, specifically the "Tumult Commission," a special category of inquiry whose primary function was to indemnify the colonial state's violent suppression of revolt. "Tumult Commission" reports, Sitze notes, read like "a history and taxonomy of hatred"; they were "almost therapeutic in their intense interest in the gradations and thresholds internal to hatred."70 The "Tumult Commission" was concerned, no less than Freud, with fingerprints of fury, which it apprehended through an

\footnotetext{
${ }^{63}$ Freud, "The Moses," 236.

${ }^{64}$ Freud, "The Claims of Psycho-analysis to Scientific Interest," 189.

${ }^{65}$ Freud, "Totem and Taboo," 1-161.

${ }^{66}$ As Spivak notes, this isomorphic relation between children and "primitive peoples" unravels with the figure of the "primitive" child. If such "primitive peoples" have children, how can they be the children of man? Spivak, "Echo."

${ }^{67}$ Freud, "The Claims of Psychoanalysis," 189-90.

${ }^{68}$ Freud, "The Moses," 230.

${ }^{69}$ Reemerge, that is, after its short-lived institutionalization in the 1930s and 1940s under the leadership of Lithuanian born analyst, Wulf Sachs who, incidentally, was also interested in black anger. Sachs, Black Anger.

${ }^{70}$ Sitze, The Impossible Machine, 166.
} 
identificatory imagination that could know and, thus, domesticate it. Sitze's key point is that the TRC is not a new deployment of psychoanalytic ideas, that it "reactualizes the therapeutic discourse already at work in the apparatus of the Tumult Commission," that before "any integration of psychoanalysis within the administrative apparatus of the TRC," the "Tumult Commission" operated as a kind of wild psychoanalysis that "interpreted the etiology of political conflict within a manifestly therapeutic horizon, searching for the psychological antidotes that colonial administrators could apply to dissipate the 'fevers' of hatred that always were at risk of swelling into open rebellion."71

This is neither to suggest that Freud, with whom I am in sympathy, as it were, is an inadvertent theorist of colonial rule, nor that he can be held accountable for his bad readers. ${ }^{2}$ My interest here, rather, is, on the one hand, in the way Freud's texts stage struggles that they cannot fully contain and, on the other, in that which is undisclosed in the apparatus that was used to mark a break with the apartheid past. A foreign concept at the heart of psychoanalysis, it was not simply from psychology that empathy was taken, but also ethnology and anthropology, with which Freud was well acquainted.73 In approaching this incorporation, I take my critical bearing from Qadri Ismail's reading of the concept of culture in the Anglo-US episteme, a concept produced mutually by the disciplines of literature and anthropology. 74

The imagination, Ismail suggests, has functioned not as the magical difference of reason, but as reason's supplement, as that which, together with reason, has come to mark the fully human subject. As Ismail reads it, Edward Tylor's Anthropology - and I focus on Tylor because he is one of the anthropologists Freud read - emplots the "lower races of men" as helplessly violent toward others, "much as children are cruel to animals through not being able to imagine."75 Staged in opposition to a "primitive" incapacity to imagine the pain and pleasure of others, it is "auto-displacement" - Ismail's term for imagining the pain of others - which appears at first "an exemplary ethical position," that is violent, for it allows one to "'partake of ' - share, participate in - and 'enter' - pierce, penetrate, possess - another desire." 76 Bringing "auto-displacement" into disturbing proximity with rape, Ismail will also, in his reading of Malinowski, the empathic anthropologist par excellence, render the production of anthropological knowledge, wherein anthropologists assume the native's point of view, as a kind of hunting. 77 Hence, if psychoanalysis has as core a concept that is foreign to it, it is a concept doubly foreign to postcolonial psychoanalysis, one whose libidinal economy is both penetrative and predatory.

\footnotetext{
71 Ibid., 206.

${ }^{72}$ Sitze pays particular attention to the figure of Jan Smuts speaking empathically in parliament in 1923 on the Bondelzwarts Commission into the 1922 air raid by the South African Government on the Bondelzwarts people in response to protests over a dog tax. ibid., 166.

${ }^{73}$ See Khanna, Dark Continents.

${ }^{74}$ Ismail, Culture and Eurocentrism. See also Mudimbe, The Invention of Africa. Mudimbe's suggests that Western ethnophilosophical apprehensions of African otherness have been given their structuring principle in Einfühlung.

75 Tylor, Anthropology, 408.

${ }^{76}$ Ismail, Culture.

${ }^{77}$ Indeed, in his introduction to Argonauts of the Western Pacific, Malinowski explicitly represents himself as the hunteranthropologist. Malinowski, Argonauts of the Western Pacific.
} 
This is ground we have already covered with Dora and Mntambo, but it repays the effort to go over it again, this time with Grégoire Chamayou's Manhunts: A Philosophical History. 78 Chamayou traces the practice of hunting for men back to antiquity, but rather than an archaic practice, he reads the manhunt as "the primal scene of conquest."79 Tracking down and exclusion, Chamayou argues, operate as distinct but complementary operations within the manhunt: technologies of predation on the one hand, but also, crucially, knowledge of the hunted on the other, which "explains why, by virtue of what difference, of what distinction, some men can be hunted and others not." 80 Chamayou places empathy within the realm of this "cynegetic power," as "hunting presupposes," he argues, "a form of empathy with the prey: to track prey effectively, one has to put oneself in its place." 81

Empathy, then, for Chamayou, is a technology of hunting, a necessary procedure, but one that confronts a contradiction at the heart of the manhunt. Empathy with the prey gives the hunt its "supreme excitement," its pleasure: one is not merely hunting an animal, but, rather, an animalized human who is like the hunter. But this leads to "the denial of the absolute social distance between masters and their slaves that the hunting relationship sought precisely to reinstate." 82 Empathy thus libidinalizes and, at the same time, undoes the manhunt, erases the difference that allows the animalized human to be an object of hunting in the first place: "If the human prey is animalized, so is the hunter, insofar as he has very animal-like feelings. Those who take pleasure in the cruel joys of manhunting are transformed and become savage." 83 Staging the developmental maturity of the modern subject, we might say with Ismail and Chamayou brought together, empathic predation unravels and fails at the very moment of its accomplishment, a predicament shared by the hunter-anthropologist, whose empathy is precisely what renders him as primitive as the natives whose point of view he inhabits.

The predicament for the prey is different, at first anyway. The prey psychically inhabiting the perspective of the hunter is not empathy, Chamayou states, but the "mastery of cynegetic logic." As he writes,

In order to anticipate the reactions of his pursuers, the hunted man has to learn to interpret his own actions from the point of view of his predator. This internalization of the perspective of the other makes him develop an extreme prudence that at first takes the form of a paralyzing anxiety of a paranoid type: seeing himself in the third person, considering with respect to each of his acts, how they might be used against him.

This produces a form of thought, Chamayou argues, through which not only the slave can evade his predator but also reverse the relation between the prey and predator:

\footnotetext{
${ }^{78}$ Chamayou, Manhunts.

${ }^{79}$ Ibid., 9. Chamayou is concerned with three historically specific forms of manhunt that haunt the modern state: "The slave-master's acquisition hunts, tyrannical sovereignty's capture hunts, pastoral power's exclusion hunts: thus, at the dawn of modernity there were three well defined forms of cynegetic power." Chamayou, Manhunts, 27.

${ }^{80}$ Ibid., 2.

${ }^{81}$ Ibid., 65 .

82 Ibid., 65.

${ }^{83}$ Ibid., 69.
} 
In doing so, the prey escapes the simple objectification that constituted his point of departure. By including in his plan of action the logic of his predator, he envelops and internalizes it. Thus he acquires, at the end of this first dialectic of tracking, the mental abilities of a hunter, whereas he is still only a prey. ${ }^{84}$

The prey can empathize, but not as prey; this remains a form of learning that must pass through anxiety and paranoia to mastery. It is not a true escape but "the tragic irony of the prey who escapes only by becoming what it sought to escape from." 85 It is only as hunter, the roles reversed, that the prey can empathize. Thus, the prey's predicament becomes, after all and through mastery, that of the predator. Indeed, in Mntambo's "The rape of Europa," the artist assumes both roles, that of Europa and Jupiter, who is no longer a snow white bull but has changed into a dark Minotaur. The Minotaur here is the predator, but the Minotaur, in the mythology and iconography Mntambo draws on, is also the hunted, the bullfighting images in The Encounter recalling the labyrinth wherein the Minotaur is killed by Theseus. Here, again, we have two figures of empathy, two figures that are really one, for the hunted is only empathic inasmuch as she can reverse the relation, and become the hunter.

When it is declared that an apartheid-era police operative like Eugene de Kock had to regain his capacity for empathy after apartheid, it is equally plausible that he already had empathy for his victims, in whose place he put himself, tracking them down. It could be argued, too, that Gobodo-Madikizela's empathy with de Kock entailed a kind of reversal of roles, the key point being that to stage post-apartheid transformation in terms of the mere occurrence of empathy is severely limited, a point that A Human Being Died that Night confronts and is the strength of Gobodo-Madikizela's intervention. ${ }^{86}$ But are instrumentalized forms of empathy - counter-insurgency operations, those staged in and around the TRC, the "Tumult Commission," in consulting rooms, in anthropological knowledge production - not to be differentiated from more intimate scenes of care and concern, from more ordinary feelings of empathy?

There are strong arguments that empathy can be used for good or bad. However, what all forms of empathy share - from Herder's eighteenth-century formulations onwards - is a concept of History, of progressional time: no conception of empathy, in the modern sense of the word, is possible without History. 87 Which is to say, at the risk of being schematic, the "target" of empathy is always rendered "primitive," the gradient of empathy runs downwards and backwards to states apprehended as less mature, less civilized. It is into this temporality of empathy that Mntambo's "The rape of Europa" intervenes, particularly when read in relation to the image it appears alongside, "Narcissus" (Figure 3), again an imaging of an Ovidian narrative. If we

\footnotetext{
${ }^{84}$ Ibid., $70-1$.

85 Ibid., 152.

${ }^{86}$ For a reading of A Human Being Died that Night, see Truscott, "A South African Story of Disavowal."

${ }^{87}$ In invoking modern empathy, I refer here to Foucault's various readings of the Renaissance concept of sympathy (it is also figured in Classical, pre-modern medicine), and which bears nothing like what we have come to understand as History. Renaissance sympathy and modern empathy share fundamentally different assumptions about time. Herder, Philosophical Writings, 272-360.
} 
have already passed through two scenes where empathy encounters its undoing, this is the third scene.

\section{An echo of empathy}

For Freud, narcissism is a "halfway phase" between "primitive" autoeroticism and the maturity of object cathexes, a rehearsal of object love - Moses grasping and then relinquishing his own body, his beard - but also that developmental point to which one regresses from object love. 88

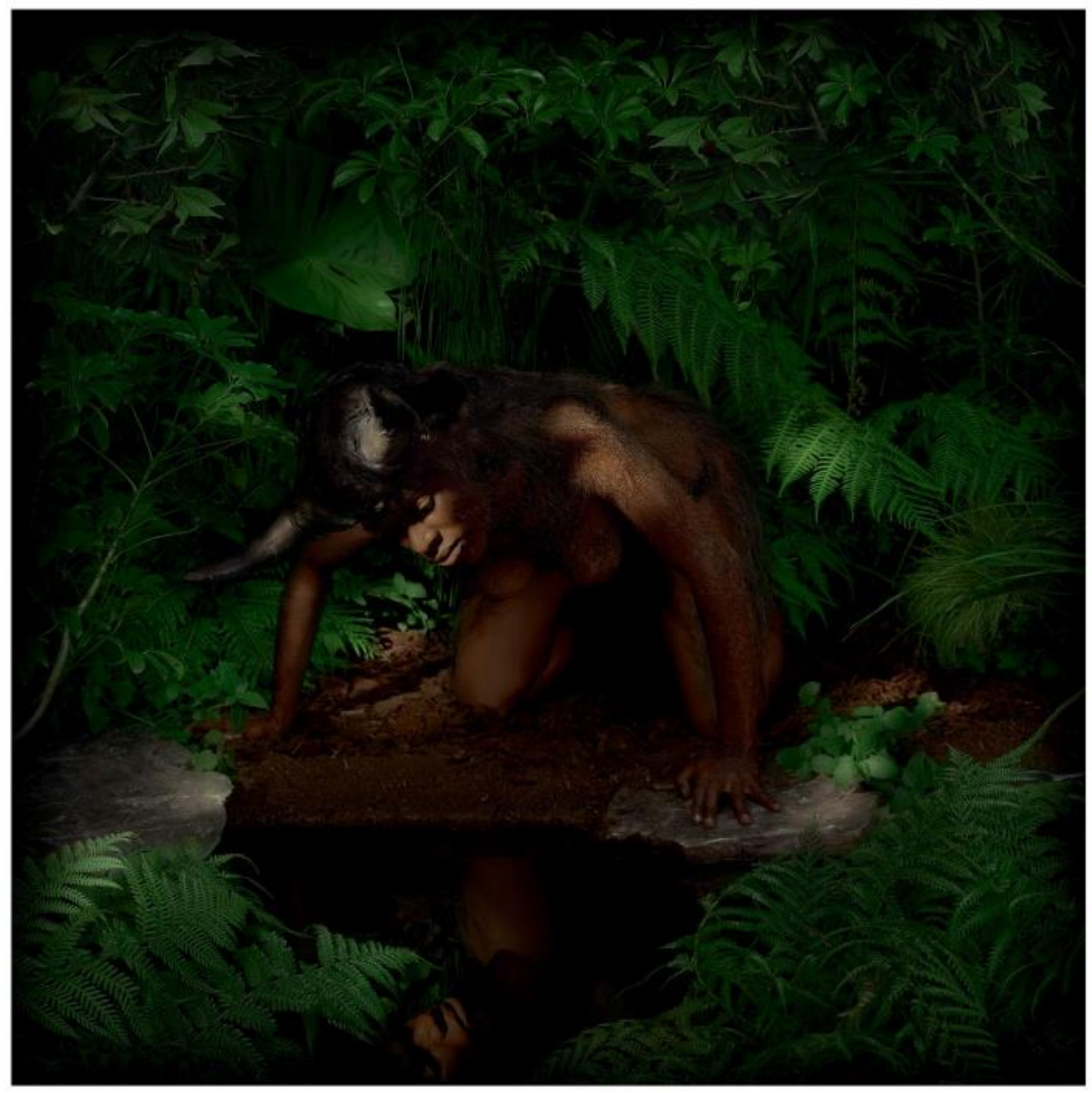

Figure 3. "Narcissus" @ Nandipha Mntambo courtesy STEVENSON Cape Town and Johannesburg.

\footnotetext{
${ }^{88}$ Freud, "On narcissism: An Introduction," 67-104. As Freud spells this out clearly in his case study of Judge Schreber: "There comes a time in the development of the individual at which he unifies his sexual instincts (which have hitherto been engaged in auto-erotic activities) in order to obtain love-object; and he begins by taking himself, his own body, as his love object, and only subsequently proceeds from this to the choice of some person other than himself as his object. This half-way phase between auto-eroticism and object-love may perhaps be indispensible normally; but it appears that many people linger unusually long in this condition, and that many of its features are carried over by them into the later stages of their development." "Psycho-analytic notes," $60-1$.
} 
Often taken to be the absence of empathy, the very opposite of empathy, narcissism confronts empathy with a paradox. In empathizing with narcissism, one must project oneself into the psychic space of a subject who cannot do so, who has withdrawn all cathexes from the world; one must imagine the impossibility of imagining another's experience. That place where empathy encounters narcissism is where it is cornered, trapped, as it were, in its own discourse. Rather than simply the limit of knowledge of the other, however, narcissism turns out to be empathy's difference and, at the same time, its disavowed animating kernel. The secret of empathy is that it is itself narcissistic. Empathizing with narcissism, the empathic subject is face to face with their own narcissism: I can inhabit your narcissism, the empathic inks, because I see in it the "primitivity" from which my mature empathic position has developed, I see reflected in the mirror of your "primitive" narcissism my own lived history (ontogenetic empathy) or that of my species (phylogenetic empathy). The racial undertones of this frame hardly require emphasis.

We are afforded a different, less teleological rendering of Narcissisus by both Spivak in "Echo" and Mntambo in The Encounter. In Narcissus and Echo, in Book II of the Metamorphoses, Echo had distracted Juno while Jupiter was with the nymphs; for this, Juno takes Echo's ability to speak for herself; she can only respond in the words of another she has just heard. Echo catches sight of Narcissisus while he is out hunting deer, and falls in love with him. She cannot initiate a conversation and a strange exchange unfolds. Echo burning with passion for Narcissisus, her love unrequited - withers until only her voice remains. Narcissus, too, will disappear. Liriope had asked the seer, Tiresias, if her son, Narcissus, would live to an old age and she is told that he will, provided he never knows himself. In love with his own reflection - this love, like Echo's, unrequited - Narcissus longs for the death of this other he sees over there, and he too disappears, only a flower remaining. There is a temptation to read Echo as a figure of empathy, imitative and resonant. For Spivak, however, Echo undoes Narcissus, she is not his mature counterpart, not narcissism surmounted, transcended; rather, she abides, critically, by Narcissus. "We must catch the undoing moment of Echo as she attends, at a distance, every act of cultural narcissism," Spivak states, to which we should add empathy as a form of narcissism. ${ }^{89}$ In their encounter in the Metamorphoses, Echo responds by repeating Narcissus' words. Spivak's argument hinges on the difference between Narcissus' call to Echo and her response, covered over in Ovid. Narcissus asks Echo why she flies from him, and Ovid, instead of giving her words, reports that Narcissus hears his words given back to him. This holds the possibility, Spivak suggests, of his question becoming her order, "fly from me." Rather than a telos - from narcissism to echoic empathy - Narcissus and Echo are a pair through which Spivak might be said to suggest: where narcissism is, there Echo will be as "the possibility of deconstruction" or, simply, of an “imperfect' repetition."9o

In Mntambo's "Narcissus," it is the artist staring at herself in the pool. This is mirrored in "The rape of Europa," where the artist plays both roles, and so, between "The rape of

${ }^{89}$ Spivak, "Echo," 27.

${ }^{90}$ Ibid., 25, 37. 
Europa" and "Narcissus," there is a third doubling, the two images asymmetrical doubles of each other. The effect generated is of a reflection of the narcissism of the empathetic gaze itself: "The rape of Europa" as a mirror in which empathy's penetrating gaze is offered its reflection, the narcissism of empathy its echo, the empathic gaze staring back at viewers who would put themselves into the enclosure of the trees, into the skin of another. And it is this gaze that is returned to the viewer, given back, like Echo might, with a difference.

If there is something echoic to be read out of Mntambo's work, it is because she inserts it into an already echoic chain, where the horizon recedes toward an always already echoic beginning: from Albrecht Durer's (1494-1495) drawing, "Rape of Europa," to Titian's (1559-1562) "Abduction of Europa" painted for the King of Spain, Phillip II, Peter Paul Ruben's (1628-1629) copy of Titian's painting, Rembrandt's (1932) "The abduction of Europa," Claude Lorrain's (1634) etching and then a later painting, "Coast scene with the rape of Europa," and Guido Reni's (1637-1639) more simply composed "The rape of Europa." Indeed, the Metamorphoses was from the start an echoic text, Ovid rewriting the rape of Europa into Book VI in the tapestries of Arachne, an archive of divine rape, which represents the event after it has been recounted at the end of Book II, an image within the story, a story repeated from the very first in a text that is itself an unfaithful echo of Virgil.

Spivak notes that a part of the framing of the Narcissus myth often excluded is that Narcissus is born of rape. In The Encounter, then, we have, on the one hand, a scene of rape in "The rape of Europa" and, on the other, "Narcissus," the child of rape. In an interview, Spivak explains her interest in writing about children of rape and the postcolonial:

Rape is something about which nothing good can be said. It's an act of violence. On the other hand, if there is a child, that child cannot be ostracized because it's the child of rape. To an extent, the postcolonial is that. ${ }^{1}$

The rape of Europa is often depicted as Europe's primal scene, its mythical origin, repetitively conjured: Europe born of a mythical rape, European colonialism as an act of rape, the postcolonial as the child of that repetitious scene acted out. Narcissus might be taken, then, as a figure of the postcolonial, at least inasmuch as he is accompanied by Echo.

Mntambo's "The rape of Europa" condenses this genealogy within a single frame. The son of this union between Jupiter and Europa, Minos, will marry Pasiphae. Minos will receive a bull from Poseidon, which he will refuse to sacrifice, and Pasiphae and the bull will produce the Minotaur. The Minotaur in this scene of Mntambo's image marks the vertical line of two generations of children to come (Minos and the Minotaur), produced from the horizontal lines of two unions (Europa and Jupiter, Pasiphae and Poseidon's bull), forming what we can refer to as the straight axis of reproductive futurity that orients the viewer to this image. 92 It is this grandchild, the Minotaur - the future, already here - acting out that primal scene. The image, however, is supported by this genealogical axis only for it to confront the viewer with its

${ }^{91}$ Spivak, "Bonding in Difference," 29, emphasis added.

${ }^{92}$ I draw this notion of an axis of straight reproduction from Sarah Ahmed's Queer Phenomenology (2006). 
impossibility: Jupiter is a woman, so too the Minotaur, from which we might conclude that, if Mntambo queers empathy, it is through a queer reproductivity, offering reproductions of classical images, placing herself, her own body, into an artistic genealogy to give birth to an impossible line of descent.

\section{Conclusion}

If empathy has been proclaimed as a threshold of psychosocial transformation, empathic identifications as the mark of colonial and apartheid relations having been transcended, the claim of this paper is that, on the contrary, empathy is integral to the order we have still to work through, that such working through - if we are to abide by this psychoanalytic term will consist in the reworking of the concept of empathy itself. It is this that Mntambo's work makes available: a notion of reproduction through which we may not have to give up on empathy. It is, however, precisely in the disclosure of empathy's dilemmas that the possibility of a post-apartheid ethics of empathy might emerge: empathy as a repetition without guarantee, a discursive reinscription rather than a clean break with the past or a threshold to be triumphantly declared.

\section{Acknowledgements}

This article was written over a long time and it has benefitted from the generous comments of several people. In particular, I would like to thank Qadri Ismail, John Mowitt, Premesh Lalu, Gary Minkley, Maurits van Bever Donker, Ranjana Khanna, Mari Ruti, Derek Hook, Leswin Laubscher and Michelle Smith. If I have not been able to take your advice, the fault is mine.

\section{Disclosure statement}

No potential conflict of interest was reported by the author.

\section{Funding}

This article was supported by grants from the National Research Foundation while I was a postdoctoral research fellow at the South African Research Initiative Chair for Social Change at the University of Fort Hare. It was supported by the Andrew W. Mellon Foundation while I was a postdoctoral fellow in the Programme for the Study of the Humanities in Africa at the Center for Humanities Research at the University of the Western Cape. It was also written in part while I was a postdoctoral fellow in Interdisciplinary Feminist Studies at Duke University. I would like to duly acknowledge, and express my appreciation for this support.

\section{Notes on contributor}

Ross Truscott is a researcher at the NRF-DST Centre for Critical Thought in African Humanities, University of the Western Cape, South Africa. He has published on psychoanalysis and postcolonial theory, post-apartheid empathy and its discontents, nationalism, popular culture, race, gender, and sexuality. 


\section{References}

Ahmed, Sarah. Queer Phenomenology: Orientations, Objects, Others. Durham: Duke University Press, 2006.

Chamayou, Grégoire, Manhunts: A Philosophical History. Trans. S. Rendall. Princeton: Princeton University Press, 2012.

Coetzee, J. M., and Arabella Kurtz. The Good Story: Exchanges on Truth, Fiction and Psychotherapy. London: Harvill Secker, 2015.

Comaroff, John and Jean Comaroff. "Portraits by the Ethnographer as a Young Man: The Photography of Isaac Schapera in 'old Botswana." Anthropology Today 22, no. 1 (2006): 9-16.

Curran, Leo. "Rape and Rape Victims in the Metamorphoses." In Women in the Ancient World: The Arethusa Papers, ed. J. Peradotto and J. P. Sullivan. Albany: State University of New York Press, 1984. 263-286.

Decker, Hannah. Freud, Dora and Vienna 19oo. Ontario: The Free Press, 1991.

Diagne, Souleymane Bachir. African Art as Philosophy: Senghor, Bergson and the Idea of Negritude. Calcutta: Seagull Books, 2011.

Du Plessis, Charl. "Have Empathy, that's What You Can Do for Constitutional Democracy Kate O'Regan.” Media24 Parliamentary Bureau, 8 September, 2015, http://www.news24.com/ SouthAfrica/News/Have-empathy-thats-what-you-can-do-forconstitutional-democracy-Kate-ORegan-20150908.

Edwards, Elizabeth. "Introduction." In Anthropology and Photography 1860-1920, ed. E. Edwards. New Haven: Yale University Press, 1992. 3-16.

Freud, Sigmund. "Fragment of an Analysis of a Case of Hysteria." In The Standard Edition of the Complete Psychological Works of Sigmund Freud, Ed. and Trans. J. Strachey. London: Hogarth Press Standard Edition, 1905, reprinted 1955, 7.

Freud, Sigmund. "The Claims of Psycho-analysis to Scientific Interest." In The Standard Edition of the Complete Psychological Works of Sigmund Freud. Ed. and Trans. J. Strachey. London: Hogarth Press, 1913a, reprinted 1955. 13: 163-190.

Freud, Sigmund. "Totem and Taboo: Resemblances between the Psychic Lives of Savages and Neurotics." In The Standard Edition of the Complete Psychological Works of Sigmund Freud. Ed. and Trans. J. Strachey. London: Hogarth Press, 1913b, reprinted 1955, 13: 1-161).

Freud, Sigmund. "The Moses of Michelangelo." In The Standard Edition of the Complete Psychological Works of Sigmund Freud. Ed. and Trans. J. Strachey. London: Hogarth Press, 1914, reprinted 1955, 13: 210-38.

Freud, Sigmund. "Group Psychology and the Analysis of the Ego." In The Standard Edition of the Complete Psychological Works of Sigmund Freud. London: Hogarth Press, 1921. 28: 69-143.

Freud, Sigmund. "Civilization and its Discontents." In The Standard Edition of the Complete Psychological Works of Sigmund Freud. Ed. and Trans. J. Strachey. London: Hogarth Press, 1930, reprinted 1955, 21: 57-146.

Freud, Sigmund. The Complete Letters from Sigmund Freud to Wilhelm Fliess: 1887-1904. Ed. and Trans. J. M. Masson. Cambridge, MA: The Belknap Press of Harvard University Press, 1985 .

Garb, Tamar. "Figures and Fictions: South African Photography in the Perfect Tense." In Figures and Fictions: Contemporary South African Photography, ed. T. Garb. Göttingen: Steidl \& V\&A Publishing, 2011. 1-85. 
Gay, Peter. "Editor's Introduction: Fragment of an Analysis of a Case of Hysteria ('Dora')." In The Freud Reader, ed. P. Gay. New York: W.W. Norton, 1989. 172-173.

Gearhart, Suzanne. "The Scene of Psychoanalysis: The Unanswered Question of Dora." In In Dora's

Case: Freud-Hysteria-Feminism, eds. C. Bernheimer and C. Kahane, 105-127. New York: Columbia University Press, 1990.

Ginzberg, Carlo. Clues, Myths, and the Historical Method. Trans. J. Tedeschi and A. C. Tedeschi. Baltimore: Johns Hopkins University Press, 1986.

Gobodo-Madikizela, Pumla. A Human Being Died that Night: A South African Woman Confronts the Legacy of Apartheid. New York: First Mariner Books, 2003.

Herder, Johann Gottfried. Herder: Philosophical Writings, 272-36o. Ed. and Trans. M. N. Forster. Cambridge: Cambridge University Press, 1774 [2008]. 272-360.

Hertz, Neil. "Dora's Secrets, Freud's Techniques." Diacritics 13, no. 1 (1983): 61-80. Ismail, Qadri. Culture and Eurocentrism. London: Rowman and Littlefield, 2015.

Khanna, Ranjana. Dark Continents: Psychoanalysis and Colonialism. Durham, NC: Duke University Press, 2003.

Koss, Juliette. "On the Limits of Empathy." The Art Bulletin 88, no. 1 (2006): 139-157.

Lacan, Jacques. "Intervention on transference." In In Dora's Case: Freud-Hysteria-Feminism, eds. C. Bernheimer and C. Kahane, 92-104. New York: Columbia University Press, 1990.

Lipps, Theador. "Empathy, Inner Imitation, and Sense Feelings." In A Modern Book of Esthetics. Einfühlung, innere Nachahmung, und Organempfi dungen, ed. M. Radar, Trans. M. Schertel and

M. Radar, 371-378. New York: Holt, Rinehart \& Winston, 1979. Originally published 1903. Lipschitz, Ruth. "Skin/Ned Politics: Species Discourse and the Limits of 'the human' in Nandipha

Mntambo's Art." Hypatia 27, no. 3 (2012): 546-566.

Mallgrave, H. F., and E. Ikonomou. "Introduction." In Empathy, Form and Space: Problems in German Aesthetics 1873-1893, ed. H. F. Mallgrave and E. Ikonomou (Trans.). Santa Monica, CA: Getty Center for History of Art and the Humanities, 1994.

Marcus, Stephen. "Freud and Dora: Story, History, Case History." In In Dora’s Case: Freud-HysteriaFeminism, eds. C. Bernheimer and C. Kahane, 56-90. New York: Columbia University Press, 1990.

May, Jackie. "The Horns of a Dilemma." Times Live Online, March 25, 2010, http://www.timeslive.co.za/opinion/2010/o3/25/the-horns-of-a-dilemma.

Mntambo, Nandipha. The Encounter. Michael Stevenson, Catalogue 41, Cape Town, 2009. Morgan, Katalin. “Typecast-Or Getting to Know You.” Mail \& Guardian, July 17-23, 2015, 26.

Mudimbe, V. Y. The Invention of Africa: Gnosis, Philosophy, and the Order of Knowledge. Bloomington: Indiana University Press, 1988.

Neill, Calum. "Beyond Identification: The (Im)possibility of Loving thy Neighbour." In Re(con)figuring

Psychoanalysis: Critical Juxtapositions of the Philosophical, the Sociohistorical and the Political, ed. A. Gülerce. Hampshire: Palgrave, 2012. 129-145.

Rieff, Phillip. "Introduction." In Dora: An Analysis of a Case of Hysteria, by S. Freud, ed. P. Rieff. New York: Touchstone, 1963. vii-xviii.

Pigman, George W. "Freud and the history of empathy." International Journal of Psycho-Analysis 76 (1995): 237-256. 
Polgreen, Lydia. "An Experiment in Empathy." Observer, September 23, 2013: 1, 4.

Richlin, Amy. "Reading Ovid's Rapes." In Pornography and Representation in Greece and Rome, ed. A. Richlin, 158-179. Oxford: Oxford University Press, 1992.

Ries, Martin. "Picasso and the Myth of the Minotaur." Art Journal 32, no. 2 (1974): 142-5.

Rose, Jacqueline. "Dora: Fragment of an Analysis." In In Dora's Case: Freud-Hysteria-Feminism, eds. C. Bernheimer and C. Kahane, 128-148. New York: Columbia University Press, 1990.

Sachs, Wulf. Black Anger. Boston, MA: Little, Brown and Company, 1947.

Sanger, Nadia. "Imagining Possibilities: Feminist Cultural Production, Non-violent Identities, and Embracing the Other in Post-colonial South Africa." African Identities 11, no. 1 (2013): 61-78. Sawicki, Marianne. "Empathy Before and After Husserl." Philosophy Today 41, no. 1 (1997): 123-127. Shelley, Percy Bysshe. "A Defense of Poetry." In Essays, Letters from Abroad, Translations and Fragments, ed. M. Shelley. London: Edward Moxon, 1839. 25-62.

Silverman, Kaja. "Masochism and Male Subjectivity." In Male Trouble, eds. C. Penley and S. Willis, 33-64. Minneapolis, MN: University of Minnesota Press, 1997.

Sitze, Adam. The Impossible Machine: A Genealogy of South Africa's Truth and Reconciliation Commission. Ann Arbor, MI: University of Michigan Press, 2013.

Smith, Cora, Glenys Lobban, and Michael O'Loughlin, ed. Psychodynamic Psychotherapy in South Africa: Contexts, Theories, Applications. Johannesburg: Wits University Press, 2013.

Spivak, Gayatri Chakravorty, "Echo." New Literary History 24, no. 1 (1993): 17-43.

Spivak, Gayatri Chakravorty, "Bonding in Difference: Interview with Alfred Arteaga." In The Spivak Reader, eds. D. Landry and G. Maclean, 15-28. London: Routledge, 1996.

Titchener, Edward B. Lectures on the Experimental Psychology of the Thought-Processes. New York: Macmillan, 1909.

Tylor, Edward Burnett. Anthropology: An Introduction to the Study of Man and Civilization. London: Macmillan, 1881.

Van der Vlies, Andrew. "Queer Knowledge and the Politics of the Gaze in Contemporary South African Photography: Zanele Muholi and Others.” Journal of African Cultural Studies, 24, no. 2: $140-156$

Vischer, Robert. "On the Optical Sense of Form: A Contribution to Aesthetics." In Empathy, Form, and Space: Problems in German Aesthetics, 1873-1893, ed. H. Francis. Santa Monica, CA: Getty Centers, distributed by the University of Chicago Press, 1994.

Žižek, Slavoj. Violence: Six Sideways Reflections. New York: Picador, 2008. 